1988

\title{
Hiring and Retention of Minorities and Women on American Law School Faculties
}

Richard H. Chused

New York Law School, richard.chused@nyls.edu

Follow this and additional works at: http://digitalcommons.nyls.edu/fac_articles_chapters

\section{Recommended Citation}

137 U. Pa. L. Rev. 537 (1988-1989)

This Article is brought to you for free and open access by the Faculty Scholarship at DigitalCommons@NYLS. It has been accepted for inclusion in Articles \& Chapters by an authorized administrator of DigitalCommons@NYLS. 


\title{
THE HIRING AND RETENTION OF MINORITIES AND WOMEN ON AMERICAN LAW SCHOOL FACULTIES
}

\author{
RICHARD H. CHUSED $\dagger$
}

At the request of the Society of American Law Teachers ("SALT"), I updated a SALT-sponsored survey of law school faculty composition for the 1980-81 academic year by adding data from the 1986-87 school year. ${ }^{1}$ The new study also includes a first look at departure rates of women and minority faculty members between 1981 and 1987. Faculty members at 149 schools, over eighty-five percent of the American Association of Law Schools" ("AALS") member institutions, returned survey questionnaires. ${ }^{2}$ This rate of return is significantly better than that of any other similar study. The sample data base

+ Professor of Law; Georgetown University Law Center; Society of American Law Teachers, 1988. This study was performed at the request of the Board of Governors of the Society of American Law Teachers (SALT), of which $I$ am a member. SALT provided funds for preparation and distribution of the forms used to collect the data. I extend both gratitude and affection to those who have sat with me on the SALT Board over the years. Collectively, the members of the Board have provided institutional and moral support for studies and projects that others in our profession find no time to perform. Special thanks go to SALT members Richard Solomon at Southwestern, Charlene Smith at Washburn, and Carol Roehrenbeck and Steve Friedland at Nova who helped me distribute questionnaires to schools lacking a SALT member on their faculties. Additional special thanks go to SALT Board members Pat Cain, David Chambers, Emma Jordan, Chuck Lawrence, Judith Resnik, Elizabeth Schneider, Marjorie Shultz, and Wendy Williams, each of whom read and commented on earlier drafts of this study. Mistakes are entirely the responsibility of the author.

1 The findings on hiring of minority persons in the earlier study, undertaken by David Chambers, were published in 1984 SALT Newsletter No. 1 (July 1984). Those data are discussed at length in Lawrence, Minority Hiring in AALS Law Schools: The Need for Voluntary Quotas, 20 U.S.F. L. Rev. 429, $439-49$ (1986). Materials from SALT studies relevant to hiring of women may be found in Chambers, SALT Survey: Women in Law School Teaching, 1983 SALT NEwSLETTER at 1, 3; Chused, Faculty Parenthood: Law School Treatment of Pregnancy and Child Care, 35 J. Legal EDuc. 568, 569-82 (1985).

To ensure that data for the 1986-87 school year were comparable to those for the 1980-81 school year, the earlier data were recollected in the process of the present study.

${ }^{2}$ Questionnaires were sent to all 174 member and fee paid institutions. One questionnaire was sent to each school. The questionnaires requested information on all full time AALS professors for the academic years 1980-81 and 1986-87 who were teaching at the school receiving that particular questionnaire. The questionnaire classified professors by race, gender, tenure status, and job description. Tenure status was broken down among those with tenure, those without tenure, and those working under nontensure track contracts. Job description was subdivided among those working in classrooms, clinics, legal writing programs, other teaching duties, library, or administration. 
is large enough to make some important observations about racial and gender patterns in the hiring, retention, and firing of faculty by American law schools. ${ }^{3}$

In general, law school faculties ${ }^{4}$ were somewhat more integrated, both by race and by gender, in the 1986-87 academic year than they were in the 1980-81 academic year. In the 1986-87 academic year, twenty percent of full time faculty were female, compared to 13.7 percent six years earlier. Last year, black faculty members constituted only 3.7 percent of majority-operated law schools' faculty, just slightly greater than the 2.8 percent figure in 1980-1981. The Hispanic proportion of majority-run faculties went from 0.5 percent to only 0.7 percent, and the proportion of other minorities from .5 percent to 1.0 percent in the same period..$^{5}$ In 1986-87, a typical law school faculty had thirty one members, ${ }^{6}$ including those teaching in classrooms and clinics, or holding positions as head librarians or academic deans. ${ }^{7}$ Of these thirty one people, twenty seven taught in classrooms, two taught in clinics, one was dean, and one ran the library; thirty were white and one was black, Hispanic, or other minority; twenty six were men and five were women. ${ }^{\mathbf{s}}$

Significant problems lurk behind these general trends. Law school faculties have never had many minority teachers in their ranks. That is

3 The gender proportions of the sample mirror the patterns generally prevalent in law schools. The overall proportion of women in my sample for the 1986-87 academic year is 20.0 percent. See App., infra, Table 2. The American Bar Association reported a figure of 20.4 percent for the same time period. See A Review of Legal Education in the United States: Fall 1986, 1987 A.B.A. SEC. LEG. EDuc. AND Admissions to B. 66 [hereinafter ABA-1986]. The ABA's figure for full-time minority teachers was 6.3 percent. My number, at 7.0 percent $(363 / 5168)$, is somewhat higher. This result suggests that the schools not represented in the sample are doing worse than the schools for which we have data. For only majority-operated institutions, my number is 5.4 percent (272/5064). See App., infra, Table 1.

* This study includes data on tenured and tenure-eligible classroom and clinical teachers, full-time clinical and legal writing teachers in contract rather than tenure track positions, head librarians, primary deans, visitors, and other types of full-time faculty. Part-time faculty were excluded, as were administrators and library staff.

- See App., infra, Table 1. The number of Hispanic teachers is so low that tabulations other than the gross number of teachers are useless. Attempts to break the population down into categories would produce cell populations too small to be used for comparisons. Unless otherwise noted, the figures for faculty membership embrace all full-time teachers, including clinical and legal writing staff, those on contracts rather than in tenure track jobs, and head librarians.

Typicality is defined as median.

7 Faculty teaching legal writing on contract rather than in tenure track positions are not included. Sixty-three of the 149 reporting schools had contract legal writing positions. The median size of these 63 legal writing staffs was three. Typically, two of the three were women.

${ }^{8}$ See App., infra, Tables 3, 4, \& 7. The Tables, in addition to providing raw figures, show cumulative percentages so that medians are readily discernable. 
problem enough. The data, however, demonstrate that minority professors in general, and black professors in particular, tend to be tokens if they are present at all; ${ }^{*}$ that very few majority-run schools have significant numbers of minority teachers; and that minority teachers leave their schools at higher rates than do their white colleagues. ${ }^{10}$ Gender issues disclosed by the study are somewhat different. Women are entering law school teaching in non-tenure track contract positions to teach legal writing at very high rates, ${ }^{11}$ about a fifth of the reporting schools are not moving at an appropriate pace to add women to their regular teaching staffs, slightly under two-fifths of the "high prestige" institutions are significantly behind the national pace in adding women to their faculties, and some schools are denying tenure to women at disproportionate rates.

\section{Hiring, Firing, and Retention of Black and Minority FACULTY}

\section{A. General Patterns}

Racial tokenism is alive and well at American law schools. About one third of all schools in this study have no black faculty members. ${ }^{12}$ Another third have just one. Less than a tenth have more than three. In percentage terms, less than fifteen percent of law schools have more than six percent of their faculty positions held by black people. ${ }^{13}$ Of this small group of nineteen schools, slightly more than half are located

See id. Tables 3 \& 4.

10 Such difficulties are by no means restricted to legal education. Declining levels of black enrollment in college and graduate education, and stagnant or declining rates of employment of blacks in teaching at all levels, have become nationally recognized problems. See generally American Council on Education, OfFice of Minority Concerns, Minorities in Higher Education: Sixth Annual Status Report (1987).

${ }_{11}$ See App., infra, Table 2. A small number of schools have more women as legal writing instructors than in all other faculty positions. Even if these schools are not overtly "steering" women into the less prestigious legal writing slots, see infra notes 85-88 and accompanying text, the pattern is disturbing. In fact, out of the $116 \mathrm{new}$ contract legal writing positions created, 100 were filled by women. See App., infra, Table 2.

12 The present tense indicated in discussions of this study is, of course, the 198687 school year.

13 See App., infra, Table 3 \& 5. The majority-operated schools with more than six percent of their faculty positions occupied by black persons during the 1986-87 academic year were University of Akron, University of Arkansas at Fayetteville, U.C.L.A., Catholic University, C.U.N.Y. at Queens, Cooley School of Law, Georgetown University, Georgia State University, Harvard University, Hofstra University, University of Kentucky, Loyola at New Orleans, Northeastern University, University of Pittsburgh, Rutgers University at Newark, University of San Francisco, Seton Hall University, Temple University, and Wayne State University. 
in large metropolitan areas in the Northeast. ${ }^{14}$ Only about one-fourth of law schools surveyed, a total of thirty nine schools, have more than six percent of their faculty positions occupied by minority persons. ${ }^{15}$ Of these schools, about thirty percent were in large northeastern cities, and just over twenty-three percent were in large southern or western cities. ${ }^{16}$ For the entire group of 144 majority-operated schools in this study, the total number of black teachers increased at a rate of only eleven people per year between 1981 and 1987.17 The population of minority teachers generally rose by only about seventeen people per year over that same interval. ${ }^{18}$ There are so few minority legal writing teachers that the category does not yield useful comparative information. The data for tenured, tenure-eligible, and clinical faculty are considerably more usable. The analysis in this Article, therefore, focuses on the latter categories.

\section{Tenure and Tenure Track Positions}

The proportion of black tenured or tenure track faculty members increased about thirty percent between 1981 and $1987 .^{19}$ While this shift may seem impressive, the extremely small size of the black teaching pool in 1981 minimizes the significance of this rate of change. In sheer numbers, the increase has been very small. There were only thirty five more tenured black professors in 1987 at the 144 non-minority-operated schools in the sample than there were in 1981. This repre-

14 See id. Table 12. As Table 12 indicates, ten of the 19 schools with more than six percent of their faculty positions occupied by black persons were in the northeast.

${ }_{15}$ See id. Table 6. Table 6 shows that 27.1 percent of schools passed the six percent minority test. For a further analysis, by region and size of metropolitan area, of these schools, see id. Table 13. The schools supplementing the list found in note 12 supra, are those schools in which black professors hold less than six percent of the faculty positions, but minority professors, generally, hold six percent or more of the faculty positions, are Albany School of Law, University of California at Hastings, University of Colorado, Columbia University, University of Detroit, University of Hawaii, University of Houston, University of Iowa, Memphis State University, New England School of Law, University of New Mexico, Ohio State University, University of Oklahoma, Southern Illinois University, Stanford University, Tulane University, Washburn University, University of Washington, University of Wisconsin and Yale University.

${ }_{16}$ See App., infra, Table 13. Table 13 shows that 30.8 percent (12/39) of all schools passing the six percent test were in large northeastern cities, and 23.1 percent $(9 / 39)$ were in large southern and western cities.

17 See id. Table 1. Total figures given in the first two columns of Table 1 yield this average rate.

${ }_{18}$ See id. Table 1.

19 From Table 1 in the Appendix, 2.8 percent (107/3886) of tenured and tenure track professors in 1981 were black. That proportion increased to 3.7 percent (159/ 4275) in 1987. 
sents an increase of only about one-quarter of a person per institution. The number of tenure track black professors increased by only sixteen in the same time period, or about one-ninth of a person per institution. ${ }^{20}$ Even if all minority faculty are taken into account, only about two-thirds of a minority teacher per school has been added to the law school teaching ranks. ${ }^{21}$

\section{Clinical Teachers}

Although blacks made up a somewhat higher portion of clinical teachers than of classroom teachers in 1981, the rate of progress for clinical teachers has been very slow in the last six years. Starting from a base of 4.3 percent $(11 / 257)$ in 1981 , black teachers constituted only 4.8 percent (18/372) of clinicians in $1987 . .^{22}$ The trend is made even more disturbing by the entry since 1981 of a single new law school-G.U.N.Y. Queens-that added six black clinicians at once. If that school is removed from the 1987 data, only 3.5 percent $(12 / 343)$ of clinicians were black. ${ }^{23}$ That represents a decline of about twenty percent in the proportion of clinicians who are black.

\section{B. Future Hiring Prospects for Minority Teachers}

Hiring more minority teachers will be difficult if there are few positions to fill. Creation of new teaching positions through faculty expansion and establishment of new law schools is unlikely to be a great source of future hiring flexibility. There is, however, a significant amount of turnover in law school faculties. Turnover, in fact, has been quite high in the last six years. There was plenty of room, largely unused, for significant improvement in faculty diversity. It will take another study in a few years to determine whether the rate of faculty departures remains high, but the trends discovered here suggest that turnover provides ample leeway for law schools committed to increasing

20 Even if the entire teaching population used in Table 1 is taken into account, there were only 64 more black persons in law teaching in 1987 than there were six years earlier, or less than one-half of a person per school. As the next section of the paper suggests, women have fared better. There were a total of 406 more women at the 149 schools in the survey in 1987 than in 1981, or an average increase of almost three per school. See App., infra, Table 2.

21 See id. Table 1. At the 144 majority-operated schools, the total population of minority teachers rose by 100 . Tenured minority teachers increased by 49 and tenure track by 30 . The rest of the increase occurred in various other categories.

22 See id.

${ }^{23}$ G.U.N.Y. Queens had 29 clinicians in the 1986-1987 academic year, of whom six were black, one was Hispanic, and two were from other minority groups. 
the number of minority teachers to successfully institute novel hiring plans.

\section{Faculty Expansion and Establishment of New Law Schools}

Law school teaching is not likely to be a growth profession in the future. The average faculty size at non-minority operated law schools grew by just under three slots ${ }^{24}$ between 1981 and 1987, and four of the 144 schools in this sample were created during the six year study interval; ${ }^{25}$ that rate of growth, however, is unlikely to continue. During the period of this study, application rates to law schools fell. ${ }^{28} \mathrm{Al}$ though that pattern changed for the class entering law schools this fall, demographics of the country do not suggest a growth in demand in the next decade. Furthermore, law school faculties are aging. The baby boomers are now tenured. There was a 12.8 percent growth in the number of teachers between 1981 and $1987,{ }^{27}$ but virtually all of that increase occurred at the tenured faculty level. ${ }^{28}$ The number of classroom and clinical teaching positions held by untenured persons actually declined by over sixteen percent. ${ }^{28}$ This trend suggests that traditional tenure track positions will become increasingly more precious. In addition to tenured faculty, the other growth areas were in clinical and legal writing positions. ${ }^{\text {so }}$

24 The 139 non-minority-operated schools reported 4485 faculty, or 32.3 per school, in 1981 . By 1987 , the 144 non-minority schools reporting data had 5071 faculty or 35.2 per school. This statistic includes legal writing instructors. Without those teachers, average faculty size grew from 31.6 to 33.7 .

${ }^{25}$ Although the tables in the Appendix consistently refer to five fewer schools in 1986-1987 than in 1980-1981, one of these data sets is from a respondent who only provided information for the most recent year. The school has existed for quite some time.

${ }^{26}$ Law school enrollment hit its peak in the 1982-83 academic year at 127,828 . Attendance gradually dropped to just over 123,000 by the 1986-1987 school year. LSAT administrations fell precipitously in the same period from 118,565 to 91,921 . See ABA-1986, supra note 2, at 66. LSAT administrations rose in the 1987-1988 academic year to 100,751 , and enrollment of first year students rose slightly to 41,055 . See FALL 1987 A.B.A. Sec. Leg. Educ. \& Admissions to B., 66.

${ }^{27}$ When considering all law schools in this sample, 4587 slots grew to 5175 , an increase of 588. See App., infra, Table 2.

${ }^{28}$ The number of tenured professors in the sample increased by 560 , from 2889 to 3449 , an increase of 19.4 percent. See id.

${ }^{28}$ The total number of tenure track positions (including clinical ones) declined from 1080 to 903 , a fall of 177 positions, or over 16 percent.

${ }^{30}$ Clinical positions increased from 278 to 386 . (Clinical tenured positions rose from 53 to 95 , tenure eligible positions rose from 59 to 86 , and clinical contract positions from 166 to 205.) Legal writing spots more than doubled from 102 to 218. The legal writing positions were all contract, not tenure track, positions. (Regular tenure track faculty teaching legal writing were not coded separately.) 


\section{Turnover}

Turnover is the only other source of new teaching positions. There were many more departures from law school faculties than I had suspected. 26.9 percent of the entire 1980-81 teaching population left teaching by $1987 .{ }^{31}$ Turnover rates, of course, varied enormously among different sorts of personnel. As the following table on turnover rates indicates, tenured teachers had the lowest turnover rate, while clinical and legal writing instructors on contract status had the highest. ${ }^{32}$

Table 1:

TURNOVER RATES

Still at Gone From Gone, But

Group:

Orig. Sch.

Orig. Sch. At New School

Tenured

$75.1 \%$

$18.8 \%$

$6.1 \%$

Tenure Track

$55.1 \%$

$31.9 \%$

$13.0 \%$

Glinical Contract

$33.1 \%$

$58.9 \%$

$8.0 \%$

Legal Writing

Contract

$7.0 \%$

$76.0 \%$

$17.0 \%$

Other ${ }^{b}$

$37.1 \%$

$50.1 \%$

$12.8 \%$

Total

$51.8 \%$

$27.9 \%$

$9.3 \%$

aTenure and tenure track figures include both classroom and clinical teachers.

b This category includes classroom teachers on contract status (usually those teaching full time just before retiring), visitors, librarians and a scattering of other sorts of positions.

s1 See App., infra, Table 10. The data in this table are divided into three basic segments: those faculty staying at their institutions, those departing and not turning up at another school, and those departing for other institutions. Those in the last group create openings at the institutions they leave, but fill them at the places to which they migrate. For overall turnover rate purposes, therefore, they create a "wash." The 26.9 percent $(1208 / 4485)$ figure is the size of the middle group. The data were gathered by taking the entries for each 1980-1981 faculty member reported as leaving her institution before the 1986-1987 academic year and searching the 1986-1987 Directory of Law Teachers to see if she had joined another school.

32 The combined turnover data for all majority-operated schools in the sample did not produce any notable differences in tenure denial rates by race or gender. As will be noted later, some important differences in tenure rates arose by gender when the schools were divided into groups defined by the number of tenured women on their faculties. The size of the sample for minority teachers, however, was small, making it impossible to subdivide the group for further analysis. 
Even though law schools are becoming increasingly tenured, a large number of teaching positions opened between 1981 and 1987. Among tenure and tenure track positions for both classroom and clinical teachers, 868 positions opened, indicating a turnover rate of 22.3 percent. $^{33}$ Even if turnover slows in the future, law schools will have many opportunities to hire minority persons. The rapid increase in the number of women teachers in the last decade confirms that a national commitment to alter present racial hiring patterns would have a very noticeable effect. ${ }^{34}$

The lack of significant progress in increasing the number of minority teachers in our ranks is reason enough to call for a nationwide alteration in law school hiring practices. Data on departure rates of black teachers suggest additional reasons for paying special attention to this problem. Turnover data, when broken down by race, indicate that white and black teachers leave their institutions at different rates. ${ }^{35}$ Of the approximately twenty-five percent of white tenured professors who left their schools between 1980 and 1986, just under half retired or died. $^{36}$ Black tenured professors left in a slightly larger proportion, about thirty percent, and only one-fifth of those leaving retired or died. ${ }^{37}$ Though the difference does not seem large, it is probably significant. $^{38}$ As the rates of retirement and death suggest, white tenured professors are older than their black peers. If retirements and deaths are excluded from the data in an effort to account for the age difference, then 85.5 percent $(2082 / 2431)$ of white tenured teachers stayed at their institutions, compared to only seventy-five percent $(36 / 48)$ of black teachers. In this population only 7.5 percent $(182 / 2431)$ of white tenured teachers left the profession, compared to 16.7 percent $(8 / 48)$ of black professors.

33 See App., infra, Table 10.

34 This statement is not meant to suggest that hiring of women is no longer a problem. As this paper suggests, quite the contrary is true. Rather, the increase in the number of women by over 400 in six years suggests that there was, and will be in the future, room for spectacular increases in the number of minorities in law teaching. That it did not happen over the last six years is certainly no excuse for it not happening in the next six.

35 See App., infra, Table 11. This table only compares the experience of white and black classroom and clinical teachers who had tenure or were in a tenure track in 1981. There were too few blacks in other job categories to undertake any meaningful data manipulation.

${ }^{36}$ Of the 683 white tenured faculty who left their schools, 334 (48.9 percent) retired or died, 167 (24.5 percent) went to other schools, and 182 (26.6 percent) left teaching. See id.

${ }^{37}$ Of the 15 black tenured faculty who left their schools, three (20.0 percent) retired or died, four (26.7 percent) went to other schools, and eight (53.3 percent) left teaching. See id.

ss See infra notes 40 . 
Among tenure track faculty, 44.3 percent (434/979) of the white teachers died, retired, or left their schools, compared to 51.8 percent $(29 / 56)$ of black teachers. This disparity arose because twice as many black non-tenured professors moved to other schools before their tenure decisions were made. ${ }^{39}$ The combined data for tenured and tenure track faculty suggest that more non-tenured black teachers shift schools after their hiring but before their tenure decisions and that more tenured black teachers leave teaching altogether after surviving the tenure gauntlet. The same trends appeared for other minority teachers, although they constitute too small a population to allow any statistically significant conclusions. The data, including information for black, Hispanic and other minority teachers as a group, are summarized in the table below.

Table 2:

\section{TURNOVER RATES - TENURED AND TENURE TRACK FACULTY BY RACE (RETIREMENTS AND DEATHS EXGLUDED) ${ }^{\mathrm{a}}$}

White Black All Min. White Black All Min. Group: Tenured Tenured Tenured Ten. Tr. Ten. Tr. Ten. Tr.

\begin{tabular}{lcccccc}
\hline \hline Still at & $85.6 \%$ & $75.0 \%$ & $73.4 \%$ & $56.4 \%$ & $48.2 \%$ & $47.9 \%$ \\
Same Sch. & $(2082 / 2431)$ & $(36 / 48)$ & $(47 / 64)$ & $(545 / 966)$ & $(27 / 56)$ & $(34 / 71)$ \\
Gone From & $7.5 \%$ & $16.7 \%$ & $17.2 \%$ & $31.0 \%$ & $32.1 \%$ & $32.4 \%$ \\
Teaching & $(182 / 2431)$ & $(8 / 48)$ & $(11 / 64)$ & $(299 / 966)$ & $(18 / 56)$ & $(23 / 71)$ \\
Gone to & $6.9 \%$ & $8.3 \%$ & $9.4 \%$ & $12.6 \%$ & $19.6 \%$ & $19.7 \%$ \\
New Sch. & $(167 / 2431)$ & $(4 / 48)$ & $(6 / 64)$ & $(122 / 966)$ & $(11 / 56)$ & $(14 / 71)$ \\
\hline \hline
\end{tabular}

a Most of the data in this study are simply reports of numbers without comparisons among characteristics of teachers. When comparisons using cross tabulations are made, as in the table in the text, a statistical measure called the chi-square test is typically used to measure the independence of the variables and ascertain the significance of the result. Independence refers to the probability of one event being affected by the occurrence or nonoccurrence of another event.

[C]hi-square test statistics that are used in practice can be viewed as being equivalent to quadratic forms of the type $=s 1 Q=Q(y)=y^{\prime} v^{-1} y$, where $y$ is a $(u \times 1)$ vector of random variables which approximately has the multivariate normal distribution $\mathrm{N}\left(\mathrm{o}_{\mathrm{u}}, \mathrm{V}\right)$, where $\mathrm{O}_{\mathrm{u}}$ is a $(u \times 1)$ vector of $O$ 's and $\chi$ is a $(u \times u)$ positive-definite covariance matrix; so $Q$ has a chi-squared distribution with $u$ degrees of freedom (d.f.) because it can be expressed as the sum of the squares of $u$ independent normal $N(O, 1)$ random variables.

1 Encyclopedia of Statistical Sciences 442 (S. Kotz \& N. Johnson eds. 1981). If the chi-square statistic and the degrees of freedom are known, then the probability $(p)$

so See App., infra, Table 11. 
that the results of the table can be ascribed to chance can be tabulated. In general if $p$ is less than .05 , most social scientists are willing to label the relationships displayed by the cross tabulation as "significant." This means that there is less than a five percent risk that the differences found among groups result from chance. Comparing the data only for white and black teachers in this table, $\chi^{2}=5.95, \mathrm{df}=2$ and $\mathrm{p}=.051$ for tenured professors, an arguably significant result. For tenure track positions, $\chi^{2}=2.66, \mathrm{df}=2$ and $p=.264$, a result not generally deemed statistically significant. Comparing white and all minority teachers, for tenured faculty, $\chi^{2}=9.24, \mathrm{df}=2$ and $p=.010$ a statistically significant result; for tenure track faculty, $\chi^{2}=3.44, \mathrm{df}=2$ and $p=.179$. The differences between white tenure-track teachers and all minorities taken together are therefore less likely to have resulted from mere chance than those between white tenure-track teachers and blacks alone; but they are still not statistically significant.

There are several possible explanations for this outcome. First, it could simply reflect the low population of black teachers in the data. A larger sample might not produce the noted differences. ${ }^{40}$ Second, some tenure track minority professors may be searching for the "right" school. Because they leave the profession completely at about the same rate as white professors, it is difficult to argue that the teaching services they provide as a group are valued less than those provided by whites. ${ }^{41}$ Rather, the numbers may simply be confirming what we intuitively understand, that being a minority token in a majority institution can be extremely difficult. Third, the numbers may indicate that some law schools are actively searching for promising young black teachers, prompting institutional shifts early in careers, and that other callings, for example judicial appointments, are beckoning more senior faculty away from law school teaching. Regardless of the cause of the higher departure rates, law schools will have to mount intensive efforts not only to hire but also to retain minority teachers. Schools wishing to retain minority faculty members may need to hire several within a short time ${ }^{42}$ in order to avoid the sense of isolation that could prompt their departure. ${ }^{43}$

10 Note that the results for tenured professors are statistically significant, but those for tenure track professors are not. See supra note 43 (describing the significance of Table 18).

11 Though I did establish a prestige ranking for schools with the intent of testing whether minority professors move to less or more prestigious institutions, the sample size was too small to make such a comparison statistically meaningful.

12 The University of Wisconsin recently hired four minority teachers in one hiring season. This effort to remedy the lack of diversity on their faculty should be widely commended, as SALT will do at its annual dinner during the AALS meetings in January 1989 by bestowing its yearly award of merit upon the University of Wisconsin. The effect of their effort does not appear in this study, since the new faculty members are beginning work at Wisconsin in stages running from this fall through the fall of 1989.

43 The data gathered in this study were structured to enable testing of the hypothesis that minority faculty would depart at higher rates from schools with low percentages of minority colleagues than from schools with high percentages of minority teachers. Such data are reported for women in Table 18. When similar tables were run by 
Finally, continual chatter among law school faculties suggests that the pool of qualified minority persons is so small that faculty diversification is impossible. There is reason to doubt the validity of this perception. Some schools, including a few "high prestige" have hired significant numbers of minority persons. ${ }^{45}$ Those who have not made much hiring progress must, therefore, bear the burden of demonstrating the absence of a qualified pool. Furthermore, data suggest that the applicant pool, even as defined by the most traditional hiring standards, ${ }^{46}$ may be growing more rapidly than faculties are diversifying. In the 1986-1987 academic year, almost eleven percent of J.D. candidates were minorities. ${ }^{47}$ While that figure is about the same as the proportion of minority untenured teachers in tenure track positions, ${ }^{48}$ it is much larger than the overall percentage of minority teachers. In addition, at the twenty two "high prestige" institutions, 14.3 percent of third year students were minorities, as were 16.5 percent of third year students at the "big eight" law schools, ${ }^{40}$ which have historically produced a high proportion of law school teachers. ${ }^{50}$ Comparable

race, the number of minority faculty at schools with more than one minority colleague (let alone more than one tenured colleague) was so low that meaningful results were impossible to obtain. The validity of the hypothesis, however, is lent some credence by the data reported here for women.

"For a list of those schools that I have defined as "high prestige" institutions see infra note 65 .

65 In the 1986-1987 academic year, the University of California at Los Angeles had five black and one Hispanic teacher; CUNY at Queens had 10 minority teachers, six of whom were black; Georgetown had six black faculty; Georgia State had three black teachers on a small faculty of 24; Harvard had five black teachers; Houston had four, two black and two Hispanic; Loyola of New Orleans had five minority teachers, four of whom were black; New Mexico had eight minority faculty, five of whom were Hispanic; Rutgers Newark had six minority teachers, four black and two Hispanic; San Francisco had four, three of whom were black; Seton Hall had six, "with five black; Stanford had five, with two black and two Hispanic; Temple had 11, with six black and two Hispanic. Wisconsin recently hired four minority teachers who will take up their new duties between this fall and next fall.

${ }^{48}$ Nothing in this paragraph is meant to suggest that traditional hiring criteria-graduation from a "big eight" school, see infra note 49 , with high grades and journal experience-necessarily produce the best and brightest law school teachers. Much has been said, with SALT support, about the need for major restructuring of hiring criteria to reflect realistically the problems of minority applicants. See, e.g., Lawrence, supra note 1, at 432-35 (discussing traditional hiring criteria). I intend simply to assert that a steady stream of well-credentialed minority people has been entering the legal profession for quite some time.

47 For the data from which this figure was calculated, see ABA-1986, supra note 3 , at $66-67$. faculty).

8 See App., infra, Table 1 (11.4 percent for tenure track classroom and clinical

49 Berkeley, Chicago, Columbia, Harvard, Michigan, Penn, Stanford, and Yale.

so The "high prestige" and "big eight" figures were tabulated from the school tables in ABA-1986, supra note 3, at 4-62. 
figures for the 1981-1982 academic year are remarkably similar, ${ }^{51}$ suggesting that the proportion of minority persons in the pool of available teachers has been higher than that in the faculty population for quite some time.

\section{Hiring, Firing, and Retention of Women}

\section{A. Tenure and Tenure Track Positions}

The growth in the proportion of women in tenured or tenure track positions from 10.8 percent to 15.9 percent represents an improvement of approximately fifty percent within six years. ${ }^{\mathbf{5 2}}$ Women now constitute over one-third of untenured faculty who are in tenure track positions. While these figures certainly represent an improvement for women, several caveats are necessary. ${ }^{53}$ About one-fifth of the reporting law schools currently maintain faculties in which the proportion of women remains below the national average of six years ago. The "high prestige" institutions are heavily represented among these laggard institutions. ${ }^{54}$ Legal writing, moreover, may be on its way to becoming a "woman's job."

\section{B. Overall Trends at "Laggard" Schools}

The median number of women per school in positions other than legal writing posts increased from just over three to five between 1981 and $1987 . .^{56}$ A typical law school faculty contained between seven and twelve percent women in 1981, and thirteen to eighteen percent in 1987. ${ }^{\mathrm{57}}$ Nonetheless, 6.7 percent of the surveyed institutions still have fewer than three women on their faculties, ${ }^{58}$ about one-fifth of the

s1 The minority student population was 8.7 percent in 1981-82, and the black population was 4.5 percent. Among third year students at "high prestige" schools in 1981-1982 academic year, 13.4 percent were minority, and 15.1 percent of third year students at the "big eight" were minority. Sie A Review of Legal Education in the United States - 1981-1982, 1982 A.B.A. SEc. LEg. Educ. \& ADmissions To B., 646, 49-51.

${ }^{52}$ See App., infra, Table 2.

ss As in the hiring of minority teachers, the rapid growth in the number tenured teachers and decline in tenure track positions may limit future access to the profession. To date, however, this problem seems not to have halted the continuing rise in the proportion of women among law school teachers.

o4 See infra notes 63-65 and accompanying text; App., infra, Tables 2 \& 9.

ss See infra notes 82-85 and accompanying text. percent).

${ }^{56}$ See App., infra, Tables 2 \& 7 (the change was from 3.44 percent to 5.20

${ }^{57}$ See id. Table 8.

${ }^{58}$ See id. Table 7. 
schools have twelve percent ${ }^{59}$ or less of their faculty slots occupied by women, eight schools have more female legal writing instructors than women in regular teaching positions, and one faculty has somehow managed not to find any woman worthy of joining its ranks. ${ }^{60}$

The geographic distribution of "laggard" schools is far from uniform. Over thirty percent of southern institutions fall into the category, as do about twenty five percent of western schools, and just over twenty percent of midwestern law schools. Only about five percent of northeastern institutions fall in this category. Schools in metropolitan areas with populations under 250,000 also have fallen behind national hiring trends, with just over thirty five percent in the laggard category. ${ }^{61}$

Of the thirty eight northeastern law schools, only two had less than twelve percent of their faculty positions occupied by women. One of the two was Harvard. ${ }^{62}$ That fact reflects the more general finding that "high prestige" schools, while constituting only about fifteen percent of the surveyed institutions, make up over twenty five percent of the laggard schools. ${ }^{63}$ Over thirty five percent of the "high prestige" law schools have less than thirteen percent of their teaching slots occupied by women. Only about eighteen percent of all other schools may claim that dubious distinction. ${ }^{64}$ It is clear that some leading institutions are not setting a good example. ${ }^{65}$ The symbolic importance of

58 I have defined the "laggard" point at 12 percent because that was the approximate percentage of women in non-legal writing positions for the entire sample during the 1980-81 academic year. See $i d$. Table 2 . It is an approximate measure of the distance the entire sample travelled between 1981 and 1987.

${ }^{60}$ See id. Tables $7 \& 8$. The groupings described in the text are not mutually exclusive.

'See id. Table 14.

${ }^{62}$ The other was Villanova.

63 See App., infra, Table 9. Eight of the 31 laggard schools are "high prestige" institutions. The same sort of variations by prestige did not appear when race was considered. That pattern may change, of course, as the proportion of minority faculty members increases to a level where distinct institutional variations become easier to observe.

64 Because the number of high prestige schools is small, it is not possible to gather statistically useful data about whether prestige school hiring patterns vary by region or the size of metropolitan areas. It may be worth noting, however, that when such tables are created, the patterns remain perfectly consistent with the notion that high prestige carries with it higher rates of lag in hiring women.

os Everybody's "high prestige" list is somewhat different. For this study, I have selected (in alphabetical order) University of California at Berkeley, University of California at Los Angeles, University of Chicago, Columbia University, Cornell University, Duke University, Georgetown University, George Washington University, Harvard University, University of Illinois, University of Michigan, University of Minnesota, New York University, Northwestern University, University of Pennsylvania, University of Southern California, Stanford University, University of Texas, Vanderbilt University, University of Virginia, University of Wisconsin, and Yale University. The "laggards" in this group are Chicago, Duke, Harvard, Michigan, Stanford, Texas, 
their actions to the larger law school community should lead them to take immediate steps to add significant numbers of women to their faculties.

\section{G. Tenure Denial Trends and "High-Prestige" Schools}

Anecdotes about women in tenure trouble have circulated among law school faculty for years. ${ }^{86}$ It was therefore somewhat surprising to find that the data for all surveyed schools taken together indicated that departure and tenure rates were almost identical for men and women. ${ }^{67}$ This uniformity, however, masks several troubling trends. Schools with a low proportion of women on their tenured faculty grant tenure to women at lower rates than to men, while schools with higher proportions of women among their tenured ranks grant tenure to women at higher rates than to men. The presence of a certain size core of tenured women on a faculty significantly improves the likelihood that junior level women will successfully leap the tenure hurdle.

As previously noted, the proportion of women among tenured faculty is lower than it is among untenured faculty. ${ }^{68}$ This difference is much more noticeable at "high prestige" institutions. At more than eighty percent of these schools women held less than thirteen percent of the tenured positions; no "high prestige" school had more than eighteen percent women on its tenured faculty. ${ }^{69}$ Slightly more than half of other

Vanderbilt and Virginia. Honors for being at the bottom of this list go to the University of Chicago, followed closely by Stanford. A few of these "high prestige" schools are exceeding national trends in hiring women. These include Georgetown, George Washington, Minnesota, and New York University. Honors in this group go to Minnesota.

Schools not on the "high prestige" list which are also lagging include the University of Alabama, Arizona State University, Baylor University, University of Colorado, University of Dayton, Denver University, University of Detroit, Detroit College of Law, Emory University, University of Florida, Florida State University, University of Georgia, University of Idaho, University of Kentucky, University of Miami, University of Missouri at Columbia, University of Nebraska, Northern Illinois University, University of Puerto Rico, University of South Carolina, Villanova University, and University of Washington. Dayton took the honor of being the only school in the entire sample without one woman on its faculty.

${ }^{68}$ A composite description of some of those stories may be found in Chused, supra note 1 , at 584, n.32. For a recent discussion of this problem, see Angel, Women in Legal Education: What its Like to be Part of a Perpetual First Wave or the Case of the Disappearing Women, 61 TEMP. L.Q. 799 (1988).

67 The data found in Table 10 for all faculty hardly changed when broken out by gender. I have therefore not included another table.

68 See App., infra, Table 2.

68 See id. Table 16. More precisely, 18 of 22 (81.8 percent) "high prestige" schools had less than 12 percent women on their tenured faculties in the 1986-87 year. The four who had more were Duke, Georgetown, New York University, and the University of California at Los Angeles. Duke, however, had a significantly lower proportion of untenured women in 1987 than in 1981 and was on the list of schools with less 
schools had less than thirteen percent women in their tenured ranks, and almost one-fifth had over eighteen percent. ${ }^{70}$ In dramatic contrast, the gender composition of tenure-eligible faculty at high prestige and at other schools is almost identical. ${ }^{71}$

The contrast between the data for tenured and untenured teachers suggests that some "high prestige" schools may be hiring women at the same rate as other institutions but denying them tenure or losing them at higher rates. To test that hypothesis, I separated the schools in this study into two groups. The first group contained all those institutions that had more than twelve percent women on their tenured faculties in both 1980-81 and 1986-87, or moved from at or below thirteen percent to above twelve percent sometime between the two sample years. ${ }^{72}$ The second group comprised the law schools that had less than thirteen percent women on their tenured faculties in both years or slipped from above twelve percent to at or below twelve percent between 1981 and 1987. I then looked at the departure and tenure data of 1980-81 faculty for these two groups of schools. Unfortunately, the small number of untenured women at high prestige schools with less than thirteen percent women on their tenured faculty in the 1980-81 sample precluded any significant data analysis of that group. ${ }^{73}$ The data for all schools, however, revealed some very interesting trends that may indicate something about the general behavior of schools with few tenured women.

Table 18 displays the departure and tenure data for tenure-eligible men and women at schools with lower and higher proportions of tenured women. It shows that untenured men were denied tenure or

than 12 percent women on their entire faculty. See supra note 62 . The three other schools still remain well behind the almost one-fifth of normal schools that have more than 18 percent women on their tenured faculties.

70 See App., infra, Table 16. More precisely, 78 of 127 (53.6 percent) had under 13 percent women, while 23 of 127 (18.1 percent) had more than 18 percent.

${ }^{71}$ See id. Table 17. Similar data trends for tenured and tenure eligible faculty surfaced in the 1980-1981 data. Only 31.8 percent (seven of 22) of the "high prestige" schools had more than six percent women on their tenured faculty in 1980-1981, compared to 43.4 percent $(53 / 122)$ of the other schools. Comparing tenure-eligible faculty instead yielded a much smaller divergence: 81.8 percent $(18 / 22)$ of the high prestige schools and 77.5 percent (93/120) of the others had more than 12 percent women on their tenure-eligible faculties.

72 Twelve percent was selected as the dividing line because it was close to the median population of tenured women in the sample schools for the 1986-1987 academic year and because it created a group of "mentoring" women averaging between two and three in size.

${ }^{73}$ There were only 34 untenured faculty at the 22 high prestige schools in 1980 81 academic year. Of these only 21 were at schools with less than 12 percent women on their tenured faculties six years later. That sample is simply too small a group to do much with. There is clearly a need for a much larger longitudinal study to track this sort of information at prestige schools. 
left their positions at rates unrelated to the gender composition of the tenured faculty. Just over half of the men were granted tenure, about twelve percent were denied tenure, and about thirty percent left. For untenured women, however, remarkable differences appeared. At schools with higher proportions of tenured women, untenured women were denied tenure much less frequently, left at lower rates, and were granted tenure at higher rates than men. At schools with lower proportions of tenured women, the untenured women were denied tenure much more frequently, left at higher rates, and were granted tenure at lower rates than men. ${ }^{74}$

There are a number of possible explanations for this outcome. The presence of a few tenured women may result in "mentoring" relationships with younger female faculty more successful than those young men typically establish with their senior peers. Tenured women in general, or newly tenured women in particular, may vote negatively in tenure cases less frequently than men. Or, perhaps, once a group of women have crossed the tenure threshold, men begin to view the tenure process differently. Regardless of cause, it is apparent that some schools have moved much more rapidly than others to integrate women into all levels of their faculties. Although larger longitudinal studies are necessary to confirm these trends, the over-representation of high prestige schools among low-progress institutions suggests that tenure may be a serious problem for many women now working on "big name" faculties.

\section{Legal Writing Teachers}

The distaste many tenure track faculty feel for teaching first year legal writing ${ }^{75}$ has led a number of schools to create special jobs for writing instruction. This is a "growth" area in law school hiring. ${ }^{76}$ Just over two-thirds of these positions, which are generally much lower in both pay and status than regular teaching slots, ${ }^{77}$ are now held by women. ${ }^{78}$ Contract status legal writing teachers leave their institutions

74 See App., infra, Table 18.

75 See Gale, Legal Writing: The Impossible Takes a Little Longer, 44 AlB. L. REv. 298, 317-18 (1980) (citing both faculty distaste and fiscal concerns as significant deterrents to effective legal writing programs).

${ }^{78}$ See App., infra, Table 2 (in raw numbers, an increase from 102 contracted legal writing teachers at the surveyed schools in the 1980-81 academic year to 218 in 1986-87).

77 The lower pay and status does not mean they are undesirable positions. They appear to attract large numbers of very bright applicants who may find both the lower expectations and the short term of employment to be exactly what they need.

${ }^{78}$ See App., infra, Table 2. 
at vastly higher rates than tenure track faculty. Three-quarters of them turn over and out of teaching. ${ }^{79}$ These positions create a track into "regular" teaching slots for a very small number of people, and to the extent this career path functions at all, it works better for men than for women. Just under one-fifth of the contract legal writing teachers left their institutions and found other legal education positions or obtained tenure track jobs without moving. ${ }^{80}$ Twelve of those moving to new jobs were men; only six were women. Ten of the twelve men obtained tenure track positions, one became a tenure track librarian, and the last found a legal writing position. Of the six women, only three obtained tenure track jobs, one became a contract status clinician, and two obtained new legal writing positions. Thus, about twenty percent $(11 / 53)$ of the male legal writing instructors found tenure track jobs, while only about six percent $(3 / 47)$ of the women did. $^{81}$

The dramatic appearance of large numbers of women in contract legal writing positions suggests that a historically typical "women's job" pattern is emerging. ${ }^{82}$ Such a development has both positive and negative aspects. The entry of women into legal teaching is certainly to be applauded, and legal writing jobs do serve now and then as a stepping stone to traditional teaching positions for women. The data also suggest, however, that some schools may be "tracking" women qualified for a regular teaching job into legal writing positions. During the 1986-87 academic year, seven of the sixty three law schools with contract status legal writing programs, or about eleven percent, had at least as many women teaching legal writing and ineligible for tenure as they

79 See id. Table 10. This figure must be considered in light of the fact that many legal writing instructors are not necessarily teaching as a career but as a sideline or preliminary to a full time career either as a practicing attorney or other profession and, therefore, could be expected to "leave teaching."

${ }^{80}$ See $i d$. (a total of 17 percent left for other institutions; one percent received tenure track positions at the same institution).

81 Using Fisher's test for $2 \mathrm{X} 2$ tables, this relationship is statistically significant: $\mathrm{p}=.035$. A one sided test was used in this test because of the small sample size. If a two sided test were used, $\mathrm{p}=.081$.

${ }^{82}$ For a comprehensive discussion of the occupational segregation of women in the United States, see Blau \& Ferber, Women in the Labor Market, in 1 WOMEN AND Work: An Annual Review 19, 31-32 (L. Larwood, A. Stromberg \& B. Gutek eds. 1985). In 1960,1970, and 1982 statistics, women are consistently disproportionately represented in clerical positions (80.7 percent filled by women in 1982) and service jobs (for example, 96.9 percent of private household workers in 1982 were women). See id. Blau and Ferber also present statistics documenting "hierarchical segregation" in college and university faculty positions. According to their data, in the 1980-81 academic year, women constituted 10.1 percent of the full professors, 20.3 percent of associate professors, and 34.8 percent of assistant professors. In contrast, women accounted for 51.9 percent of the instructors and 46.3 percent of the lecturers. See id. at 36. 
had women in tenured or tenure-eligible positions. ${ }^{83}$ In addition, a correspondence exists between schools with a large proportion of women in legal writing positions and those with a small proportion of women on their regular faculties. All seven schools with more female legal writing teachers than female regular faculty were laggard schools. ${ }^{84}$ In addition, twenty nine percent of schools in which women held more than seventy five percent of the legal writing positions during the 19861987 academic year were laggard, while only 12.5 percent of schools with smaller proportions of women on their legal writing staffs had less than thirteen percent on their faculties. ${ }^{85}$ Although these results are not quite statistically significant, ${ }^{86}$ the trend is nonetheless troubling. The lower pay and prestige of the contract legal writing slots, together with the low rate of hiring for traditional teaching positions, creates an impression that some schools "track" women into lower status legal writing jobs rather than into classroom or clinical work, pay them less than they are worth, and then let them go.

It was not possible to test the "tracking" hypothesis fully in this study. Data on the size and qualifications of the applicant pools for legal writing, clinical and traditional teaching positions were not gathered. Nor was information sought from legal writing teachers on the reasons they applied for and accepted employment in their jobs. It is not known whether women are more interested in teaching writing than men, more likely than men to view a temporary teaching position as a convenient way to follow spouses or significant others who have obtained "good" jobs in a new location, or more inclined than men to seek legal writing positions as a means of handling child-rearing tasks. Regardless of the factors leading to the creation of a "women's job" in our midst, it is surely time for law schools to examine their hiring pro-

8s The seven schools in this category were the University of Chicago, Detroit College of Law, University of Florida, Florida State University, Miami University, Villanova University and the University of Washington. The appearance of the University of Chicago on this list is particularly disturbing since it was also the high prestige school with the least successful record in hiring women. Once again southern schools may emerge as the most suspect. Three of the 12 southern schools with contract status legal writing teachers have an equal or larger number of women as legal writing instructors than as regular faculty. This 25 percent figure is well above all the other regions, in which only eight percent (four of 50) schools had the same characteristic.

84 A laggard school is one with twelve percent or less women on their faculty. See supra note 59.

8s See App., infra, Table 15.

86 As the Note to Table 15 in the Appendix indicates, $p=.095$ for the schools with legal writing programs. While social scientists usually require that $p=.05$ or less to be significant, the results obtained here still suggest that some serious questions are in order. The linkage between large numbers of women in legal writing positions and low numbers in regular teaching positions may be attributed to chance at less than a 10 percent rate of probability. 
cedures carefully for indications of gender stereotyping that may be driving women to accept legal writing positions instead of regular faculty spots.

\section{ConCLUSION}

Commitments must be made by all American law schools to recruit, hire, and tenure black, Hispanic, Asian and other minority persons aggressively. Change has been occurring at a snail's pace. Indeed, the rate of change in minority hiring revealed by this study makes "all deliberate speed" seem like the speed of light. Commitments must be made by all American law schools to recruit, hire, and tenure women aggressively. The failure of a sizeable segment of law schools, including many of the highest stature, to hire substantial numbers of women is appalling.

The time for excuses is past. Enough schools have now attained meaningful racial and gender diversity on their faculties to make the "unavailability of qualified applicant" excuse heard from racially segregated or male faculties ring totally hollow. Turnover is high enough to make the "lack of available slot" excuse ring equally hollow. More apologies, regrets, and rationalizations are not acceptable. They must be replaced with commitment, devotion of time, willingness to confess error, conscious devotion to finding and using new methods for recruiting faculty, placement of existing women and minority faculty on hiring and tenure committees in as substantial numbers as possible, the use of substantial numbers of open faculty slots as targets for the fulfillment of openly stated hiring goals, ${ }^{87}$ and frequently articulated, strongly worded public statements by senior faculty, deans, and university presidents that faculty diversity is a matter of the highest priority.

87 The Society of American Law Teachers has previously endorsed the idea that slots be held open for minority teachers. See Lawrence, supra note 1, at 438 . The present study reaffirms the need for such a practice. 


\section{ÁPPENDIX \\ TABLE 1 - HIRING TRENDS FOR \\ BLACK AND HISPANIC FACULTY}

\begin{tabular}{|c|c|c|c|c|c|c|}
\hline $\begin{array}{l}\text { Faculty } \\
\text { Status }\end{array}$ & \begin{tabular}{|l} 
Black: \\
1980-81 \\
Acad. Yr.
\end{tabular} & $\begin{array}{l}1986-87 \\
\text { Acad. Yr. }\end{array}$ & $\begin{array}{l}\text { Hispanic: } \\
1980-81 \\
\text { Acad. Yr. }\end{array}$ & $\begin{array}{l}1986-87 \\
\text { Acad. Yr. }\end{array}$ & $\begin{array}{l}\text { Other: } \\
\text { 1980-81 } \\
\text { Acad. Yr. }\end{array}$ & $\begin{array}{l}1986-87 \\
\text { Acad. Yr. }\end{array}$ \\
\hline $\begin{array}{l}\text { Tenured } \\
\text { Classroom } \\
\text { Faculty }\end{array}$ & $\begin{array}{c}1.8 \% \\
(51 / 2788)\end{array}$ & $\begin{array}{c}2.5 \% \\
(84 / 3303)\end{array}$ & $\begin{array}{c}0.4 \% \\
(11 / 2788)\end{array}$ & $\begin{array}{c}0.4 \% \\
(12 / 3303)\end{array}$ & $\begin{array}{c}0.3 \% \\
(8 / 2788)\end{array}$ & $\begin{array}{c}0.6 \% \\
(19 / 3303)\end{array}$ \\
\hline $\begin{array}{l}\text { Tenure } \\
\text { Eligible } \\
\text { Classroom } \\
\text { Faculty }\end{array}$ & $\begin{array}{c}5.2 \% \\
(52 / 998)\end{array}$ & $\begin{array}{c}8.1 \% \\
(65 / 800)\end{array}$ & $\begin{array}{c}0.7 \% \\
(7 / 998)\end{array}$ & $\begin{array}{c}1.4 \% \\
(11 / 800)\end{array}$ & $\begin{array}{c}0.7 \% \\
(7 / 998)\end{array}$ & $\begin{array}{c}1.6 \% \\
(13 / 800)\end{array}$ \\
\hline $\begin{array}{l}\text { Tenured } \\
\text { Clinical } \\
\text { Faculty }\end{array}$ & $\begin{array}{c}\text { None } \\
(0 / 48)\end{array}$ & $\begin{array}{c}2.2 \% \\
(2 / 89)\end{array}$ & $\begin{array}{c}\text { None } \\
(0 / 48)\end{array}$ & $\begin{array}{c}2.3 \% \\
(2 / 89)\end{array}$ & $\begin{array}{l}\text { None } \\
(0 / 48)\end{array}$ & $\begin{array}{l}\text { None } \\
(0 / 89)\end{array}$ \\
\hline \begin{tabular}{|l} 
Tenure \\
Eligible \\
Clinical \\
Faculty
\end{tabular} & $\begin{array}{c}7.7 \% \\
(4 / 52)\end{array}$ & $\begin{array}{c}9.6 \% \\
(8 / 83)\end{array}$ & $\begin{array}{c}1.9 \% \\
(1 / 52)\end{array}$ & $\begin{array}{c}2.4 \% \\
(2 / 83)\end{array}$ & $\begin{array}{l}\text { None } \\
(0 / 52)\end{array}$ & $\begin{array}{c}2.4 \% \\
(2 / 83)\end{array}$ \\
\hline $\begin{array}{l}\text { Contract } \\
\text { Status } \\
\text { Clinical } \\
\text { Faculty }\end{array}$ & $\begin{array}{c}4.5 \% \\
(7 / 157)\end{array}$ & $\begin{array}{c}4.0 \% \\
(8 / 200)\end{array}$ & $\begin{array}{c}1.3 \% \\
(2 / 157)\end{array}$ & $\begin{array}{c}1.0 \% \\
(2 / 200)\end{array}$ & $\begin{array}{c}\text { None } \\
(0 / 157)\end{array}$ & $\begin{array}{c}1.0 \% \\
(2 / 200)\end{array}$ \\
\hline $\begin{array}{l}\text { Contract } \\
\text { Status } \\
\text { Legal Wr. } \\
\text { Faculty }\end{array}$ & $\begin{array}{c}1.1 \% \\
(1 / 89)\end{array}$ & $\begin{array}{c}2.4 \% \\
(5 / 212)\end{array}$ & $\begin{array}{c}1.1 \% \\
(1 / 89)\end{array}$ & $\begin{array}{l}\text { None } \\
(0 / 212)\end{array}$ & $\begin{array}{l}\text { None } \\
(0 / 89)\end{array}$ & $\begin{array}{c}0.9 \% \\
(2 / 212)\end{array}$ \\
\hline $\begin{array}{l}\text { Other } \\
\text { Categories }\end{array}$ & $\begin{array}{c}2.6 \% \\
(8 / 312)\end{array}$ & $\begin{array}{c}4.0 \% \\
(15 / 377)\end{array}$ & $\begin{array}{c}1.0 \% \\
(3 / 312)\end{array}$ & $\begin{array}{c}1.1 \% \\
(4 / 377)\end{array}$ & $\begin{array}{c}2.9 \% \\
(9 / 312)\end{array}$ & $\begin{array}{c}3.7 \% \\
(14 / 377)\end{array}$ \\
\hline Totals & $\begin{array}{c}2.8 \% \\
(123 / 4444)\end{array}$ & $\begin{array}{c}3.7 \% \\
(187 / 5064)\end{array}$ & $\begin{array}{c}0.5 \% \\
(24 / 4444)\end{array}$ & $\begin{array}{c}0.7 \% \\
(33 / 5064)\end{array}$ & $\begin{array}{c}0.6 \% \\
(26 / 4444)\end{array}$ & $\begin{array}{c}1.0 \% \\
(52 / 5064)\end{array}$ \\
\hline
\end{tabular}

NOTE ON TABLE 1: This table excludes data from minority operated institutions. Faculty whose race is not known ( 41 for 1981 and 7 for 1986) are also excluded from this table. The "Other Categories" label in the Faculty Status column includes contract status classroom faculty (usually retired faculty teaching some courses), librarians, visitors and other faculty. 
TABLE 2 - HIRING TRENDS FOR FEMALE FACULTY

\begin{tabular}{|l|c|c|}
\hline Faculty & $\begin{array}{c}1980-1981 \\
\text { Academic Yr. }\end{array}$ & $\begin{array}{c}1986-1987 \\
\text { Academic Yr. }\end{array}$ \\
\hline Tenured Class- & $5.8 \%$ & $11.0 \%$ \\
room Faculty & $(165 / 2836)$ & $(368 / 3354)$ \\
\hline Tenure Track & $23.5 \%$ & $33.8 \%$ \\
Classroom Fac. & $(240 / 1021)$ & $(276 / 817)$ \\
\hline Tenured Clinical & $13.2 \%$ & $14.7 \%$ \\
Faculty & $(7 / 53)$ & $(14 / 95)$ \\
\hline Tenure Track & $28.8 \%$ & $40.7 \%$ \\
Clinical Faculty & $(17 / 59)$ & $(35 / 86)$ \\
\hline Contract Status & $40.4 \%$ & $40.0 \%$ \\
Clinical Faculty & $(67 / 166)$ & $(82 / 205)$ \\
\hline Contract Status & $48.0 \%$ & $68.4 \%$ \\
Legal Writing Fac. & $(49 / 102)$ & $(149 / 218)$ \\
\hline Other Categories & $24.0 \%$ & $27.8 \%$ \\
& $(84 / 350)$ & $(111 / 400)$ \\
\hline Totals & $13.7 \%$ & $20.0 \%$ \\
& $(629 / 4587)$ & $(1035 / 5175)$ \\
\hline
\end{tabular}

NOTES ON TABLE 2: This table includes data from all schools, including traditionally minority operated institutions. The "Other Categories" label in the Faculty Status column includes contract status classroom faculty (usually retired faculty teaching some courses), librarians, visitors and other faculty.

"TWO-FOR'S": Minority women obviously turn up in two sorts of data calculations. In this table, 54 of the women on faculties in 1980-1981 were black, Hispanic or other minority. Excluding the 12 women whose race is unknown, those 54 persons represented $8.8 \%$ of the female faculty, or $1.2 \%$ of all faculty. For the $1986-1987$ year, 101 of the 1034 women whose race is known were minority, or $9.8 \%$. These women represented $2.0 \%$ of all faculty.

GENDER AND RACE: Black teachers are more likely to be women than white teachers. In the 1986-1987 academic years, $32.7 \%$ (70 of 214) of black teachers were women, compared to only $19.4 \%$ ( 933 of 4805 ) of white teachers. But among the generally younger teachers eligible for but not yet granted tenure, most of the racial difference in gender composition disappears. $38.8 \%$ (31/ 80 ) of black tenure eligible teachers were women, compared to $34.2 \%(268 / 784)$ for whites. 
TABLE 3 - NUMBER OF BLACK FACULTY INSTITUTIONAL TOTALS

\begin{tabular}{|c|rrrr|rrrr|}
\hline & \multicolumn{4}{|c|}{$\begin{array}{c}\text { 1980-1981 } \\
\text { Academic Yr. }\end{array}$} & \multicolumn{4}{c|}{$\begin{array}{c}\text { Academic Yr. } \\
\text { Acade }\end{array}$} \\
\hline $\begin{array}{c}\text { Number of } \\
\text { Black Fac. }\end{array}$ & $\begin{array}{c}\text { \# of } \\
\text { Schs }\end{array}$ & $\begin{array}{c}\text { \% of } \\
\text { Schs }\end{array}$ & $\begin{array}{c}\text { Cum \# } \\
\text { Schs }\end{array}$ & $\begin{array}{c}\text { Cum \% } \\
\text { Schs }\end{array}$ & $\begin{array}{r}\text { \# of } \\
\text { Schs }\end{array}$ & $\begin{array}{c}\text { \% of } \\
\text { Schs }\end{array}$ & $\begin{array}{c}\text { Cum \# } \\
\text { Schs }\end{array}$ & $\begin{array}{c}\text { Cum \% } \\
\text { Schs }\end{array}$ \\
\hline 0 & 64 & $46.0 \%$ & 64 & $46.0 \%$ & 48 & $33.3 \%$ & 48 & $33.3 \%$ \\
1 & 43 & $30.9 \%$ & 107 & $77.0 \%$ & 50 & $34.7 \%$ & 98 & $68.1 \%$ \\
2 & 24 & $17.3 \%$ & 131 & $94.2 \%$ & 32 & $22.2 \%$ & 130 & $90.3 \%$ \\
3 or more & 8 & $5.8 \%$ & 139 & $100 \%$ & 14 & $9.7 \%$ & 144 & $100 \%$ \\
\hline
\end{tabular}

NOTE ON TABLE 3: Minority-operated schools are not included in this table. The data in this table includes all full-time faculty except legal writing teachers on contract status. Classroom and clinical teachers, academic deans, head librarians, and visitors are included.

TABLE 4 - NUMBER OF MINORITY FACULTY INSTITUTIONAL TOTALS

\begin{tabular}{|c|c|c|c|c|c|c|c|c|}
\hline \multirow[b]{2}{*}{$\begin{array}{l}\text { Number of } \\
\text { Min. Fac. }\end{array}$} & \multicolumn{4}{|c|}{$\begin{array}{c}\text { 1980-1981 } \\
\text { Academic Yr. }\end{array}$} & \multicolumn{4}{|c|}{$\begin{array}{c}1986-1987 \\
\text { Academic Yr. }\end{array}$} \\
\hline & $\begin{array}{l}\text { \# of } \\
\text { Schs }\end{array}$ & $\begin{array}{l}\% \text { of } \\
\text { Schs }\end{array}$ & $\begin{array}{l}\text { Cum \# } \\
\text { Schs }\end{array}$ & $\begin{array}{c}\text { Cum \% } \\
\text { Schs }\end{array}$ & $\begin{array}{l}\text { \# of } \\
\text { Schs }\end{array}$ & $\begin{array}{l}\% \text { of } \\
\text { Schs }\end{array}$ & $\begin{array}{l}\text { Cum \# } \\
\text { Schs }\end{array}$ & $\begin{array}{l}\text { Cum \% } \\
\text { Schs }\end{array}$ \\
\hline 0 & 50 & $36.0 \%$ & 50 & $36.0 \%$ & 38 & $26.4 \%$ & 38 & $26.4 \%$ \\
\hline 1 & 42 & $30.2 \%$ & 92 & $66.2 \%$ & 37 & $25.7 \%$ & 75 & $52.1 \%$ \\
\hline 2 & 27 & $19.4 \%$ & 119 & $85.6 \%$ & 35 & $24.3 \%$ & 110 & $76.4 \%$ \\
\hline 3 or more & 20 & $14.4 \%$ & 139 & $100 \%$ & 34 & $23.6 \%$ & 144 & $100 \%$ \\
\hline
\end{tabular}

NOTE ON TABLE 4: Minority-operated schools are not included in this table. Minorities included in the data are black, Hispanic and others, such as Asians and Native Americans. The data in this table includes all full-time faculty except legal writing teachers on contract status. Classroom and clinical teachers, academic deans, head librarians, and visitors are included. 
TABLE 5 - PERGENTAGE OF BLACK FAGULTY

INSTITUTIONAL TOTALS

\begin{tabular}{|c|c|c|c|c|c|c|c|c|}
\hline \multirow[b]{2}{*}{$\begin{array}{l}\text { Percent of } \\
\text { Black Fac. }\end{array}$} & \multicolumn{4}{|c|}{$\begin{array}{c}1980-1981 \\
\text { Academic Yr. }\end{array}$} & \multicolumn{4}{|c|}{$\begin{array}{c}\text { 1986-1987 } \\
\text { Academic Yr. }\end{array}$} \\
\hline & $\begin{array}{l}\text { \# of } \\
\text { Schs }\end{array}$ & $\begin{array}{l}\% \text { of } \\
\text { Schs }\end{array}$ & $\begin{array}{c}\text { Cum \# } \\
\text { Schs }\end{array}$ & $\begin{array}{c}\text { Cum \% } \\
\text { Schs }\end{array}$ & $\begin{array}{l}\text { \# of } \\
\text { Schs }\end{array}$ & $\begin{array}{l}\% \text { of } \\
\text { Schs }\end{array}$ & $\begin{array}{l}\text { Cum \# } \\
\text { Schs }\end{array}$ & $\begin{array}{l}\text { Cum \% } \\
\text { Schs }\end{array}$ \\
\hline $0-6 \%$ & 123 & $88.5 \%$ & 123 & $88.5 \%$ & 125 & $86.8 \%$ & 125 & $86.8 \%$ \\
\hline $7 \%-12 \%$ & 14 & $10.1 \%$ & 137 & $98.6 \%$ & 15 & $10.4 \%$ & 140 & $97.2 \%$ \\
\hline $13 \%-18 \%$ & 2 & $1.4 \%$ & 139 & $100 \%$ & 4 & $2.8 \%$ & 144 & $100 \%$ \\
\hline $19 \%$ UP & 0 & - $\%$ & 139 & $100 \%$ & 0 & —\% & 144 & $100 \%$ \\
\hline
\end{tabular}

NOTE ON TABLE 5: This table does not include minority-operated schools. The data in this table includes all full-time faculty except legal writing teachers on contract status. Glassroom and clinical teachers, academic deans, head librarians, and visitors are included.

\section{TABLE 6 - PERCENTAGE OF MINORITY FACULTY INSTITUTIONAL TOTALS}

\begin{tabular}{|c|c|c|c|c|c|c|c|c|}
\hline - & \multicolumn{4}{|c|}{$\begin{array}{c}\text { 1980-1981 } \\
\text { Academic Yr. }\end{array}$} & \multicolumn{4}{|c|}{$\begin{array}{c}\text { 1986-1987 } \\
\text { Academic Yr. }\end{array}$} \\
\hline $\begin{array}{l}\text { Percent of } \\
\text { Min. Fac. }\end{array}$ & $\begin{array}{l}\text { \# of } \\
\text { Schs }\end{array}$ & $\begin{array}{l}\% \text { of } \\
\text { Schs }\end{array}$ & $\begin{array}{l}\text { Cum \# } \\
\text { Schs }\end{array}$ & $\begin{array}{c}\text { Cum \% } \\
\text { Schs }\end{array}$ & $\begin{array}{l}\text { \# of } \\
\text { Schs }\end{array}$ & $\begin{array}{l}\% \text { of } \\
\text { Schs }\end{array}$ & $\begin{array}{c}\text { Cum \# } \\
\text { Schs }\end{array}$ & $\begin{array}{c}\text { Cum \% } \\
\text { Schs }\end{array}$ \\
\hline $0-6 \%$ & 108 & $77.7 \%$ & 108 & $77.7 \%$ & 105 & $72.9 \%$ & 105 & $72.9 \%$ \\
\hline $7 \%-12 \%$ & 26 & $18.7 \%$ & 134 & $96.4 \%$ & 30 & $20.8 \%$ & 135 & $93.8 \%$ \\
\hline $13 \%-18 \%$ & 5 & $3.6 \%$ & 139 & $100 \%$ & 4 & $2.8 \%$ & 139 & $96.5 \%$ \\
\hline $19 \%$ UP & 0 & — & 139 & $100 \%$ & 5 & $3.5 \%$ & 144 & $100 \%$ \\
\hline
\end{tabular}

NOTE ON TABLE 6: This table does not include minority-operated institutions. The data in this table includes all full-time faculty except legal writing teachers on contract status. Classroom and clinical teachers, academic deans, head librarians, and visitors are included. 
TABLE 7 - NUMBER OF FEMALE FACULTY

INSTITUTIONAL TOTALS

\begin{tabular}{|c|c|c|c|c|c|c|c|c|}
\hline \multirow[b]{2}{*}{$\begin{array}{l}\text { Number of } \\
\text { Fem. Fac. }\end{array}$} & \multicolumn{4}{|c|}{$\begin{array}{c}\text { 1980-1981 } \\
\text { Academic Yr. }\end{array}$} & \multicolumn{4}{|c|}{$\begin{array}{c}1986-1987 \\
\text { Academic Yr. }\end{array}$} \\
\hline & $\begin{array}{l}\text { \# of } \\
\text { Schs }\end{array}$ & $\begin{array}{l}\% \text { of } \\
\text { Schs }\end{array}$ & $\begin{array}{c}\text { Cum \# } \\
\text { Schs }\end{array}$ & $\begin{array}{c}\text { Cum \% } \\
\text { Schs }\end{array}$ & $\begin{array}{l}\text { \# of } \\
\text { Schs }\end{array}$ & $\begin{array}{l}\% \text { of } \\
\text { Schs }\end{array}$ & $\begin{array}{l}\text { Cum \# } \\
\text { Schs }\end{array}$ & $\begin{array}{c}\text { Cum \% } \\
\text { Schs }\end{array}$ \\
\hline 0 & 4 & $2.8 \%$ & 4 & $2.8 \%$ & 1 & $0.7 \%$ & 1 & $0.7 \%$ \\
\hline 1 & 11 & $7.6 \%$ & 15 & $10.4 \%$ & 0 & — & 1 & $0.7 \%$ \\
\hline 2 & 25 & $17.4 \%$ & 40 & $27.8 \%$ & 9 & $6.0 \%$ & 10 & $6.7 \%$ \\
\hline 3 & 27 & $18.8 \%$ & 67 & $46.5 \%$ & 23 & $15.4 \%$ & 33 & $22.1 \%$ \\
\hline 4 & 30 & $20.8 \%$ & 97 & $67.4 \%$ & 24 & $16.1 \%$ & 57 & $38.3 \%$ \\
\hline 5 & 18 & $12.5 \%$ & 115 & $79.9 \%$ & 20 & $13.4 \%$ & 77 & $51.7 \%$ \\
\hline 6 or more & 29 & $20.1 \%$ & 144 & $100 \%$ & 72 & $48.3 \%$ & 149 & $100 \%$ \\
\hline
\end{tabular}

NOTE ON TABLE 7: This table has data for all schools, including minority-operated institutions. The data in this table includes all full-time faculty except legal writing teachers on contract status.

\section{TABLE 8 - PERGENTAGE OF FEMALE FACULTY INSTITUTIONAL TOTALS}

\begin{tabular}{|c|c|c|c|c|c|c|c|c|}
\hline \multirow[b]{2}{*}{$\begin{array}{l}\text { Percent of } \\
\text { Fem. Fac. }\end{array}$} & \multicolumn{4}{|c|}{$\begin{array}{c}1980-1981 \\
\text { Academic Yr. }\end{array}$} & \multicolumn{4}{|c|}{$\begin{array}{c}\text { 1986-1987 } \\
\text { Academic Yr. }\end{array}$} \\
\hline & $\begin{array}{l}\text { \# of } \\
\text { Schs }\end{array}$ & $\begin{array}{l}\% \text { of } \\
\text { Schs }\end{array}$ & $\begin{array}{c}\text { Cum \# } \\
\text { Schs }\end{array}$ & $\begin{array}{c}\text { Cum \% } \\
\text { Schs }\end{array}$ & $\begin{array}{l}\text { \# of } \\
\text { Schs }\end{array}$ & $\begin{array}{l}\% \text { of } \\
\text { Schs }\end{array}$ & $\begin{array}{c}\text { Cum \# } \\
\text { Schs }\end{array}$ & $\begin{array}{c}\text { Cum \% } \\
\text { Schs }\end{array}$ \\
\hline $0-6 \%$ & 18 & $12.5 \%$ & 18 & $12.5 \%$ & 3 & $2.0 \%$ & 3 & $2.0 \%$ \\
\hline $7 \%-12 \%$ & 55 & $38.2 \%$ & 73 & $50.7 \%$ & 28 & $18.8 \%$ & 31 & $20.8 \%$ \\
\hline $13 \%-18 \%$ & 47 & $32.6 \%$ & 120 & $83.3 \%$ & 52 & $34.9 \%$ & 83 & $55.7 \%$ \\
\hline $19 \%$ UP & 24 & $16.7 \%$ & 144 & $100 \%$ & 66 & $44.3 \%$ & 149 & $100 \%$ \\
\hline
\end{tabular}

NOTE ON TABLE 8: This table has data for all schools, including minority-operated institutions. The data in this table includes all full-time faculty except legal writing teachers on contract status. 
TABLE 9 - SCHOOL PRESTIGE AND PERGENTAGE

OF FEMALE FACULTY IN 1986-1987 ACADEMIC YEAR

\begin{tabular}{|r|rr|rr|}
\hline $\begin{array}{c}\text { Percent of } \\
\text { Fem. Fac. }\end{array}$ & \multicolumn{2}{|c|}{$\begin{array}{c}\text { Percent of "High } \\
\text { Prestige" Schools }\end{array}$} & \multicolumn{2}{c|}{$\begin{array}{c}\text { Percent of "Normal" } \\
\text { Schools }\end{array}$} \\
\hline $0-6 \%$ & $4.6 \%$ & $(1 / 22)$ & $1.6 \%$ & $(2 / 127)$ \\
$7 \%-12 \%$ & $31.8 \%$ & $(7 / 22)$ & $16.8 \%$ & $(21 / 127)$ \\
$13 \%-18 \%$ & $40.9 \%$ & $(9 / 22)$ & $33.9 \%$ & $(43 / 127)$ \\
$18 \%$ UP & $22.7 \%$ & $(5 / 22)$ & $48.0 \%$ & $(61 / 127)$ \\
\hline
\end{tabular}

NOTE ON TABLE 9: This table has data for all schools, including minority-operated institutions. The data in this table includes all full-time faculty except legal writing teachers on contract status. For this table $\chi^{2}=6.13, \mathrm{df}=3$, and $\mathrm{p}=105$. Most social scientists would not label this a statistically significant result. If data cells for schools below $12 \%$ and above $12 \%$ are combined, Fisher's Test (another significance measure for small tables) produces $\mathrm{p}=.053$, likely to be a significant result.

\section{NOTE FOR TABLES 10-11 ON THE FOLLOWING PAGES:}

The numbers represented by the percentages are in brackets. The columns for those who had tenure or were on tenure tracks in 1981 include both classroom and clinical teachers. The data did not vary much when split apart. Clinicians on contract are separated since their turnover rates were very high. Those on tenure tracks who were reported to have left because their contracts were not renewed were treated as if tenure were denied. The following abbreviations are used in the table: Ten. $=$ Tenure; Clin. $=$ Clinical; Cont. $=$ Contract; LW=Legal Writing; Den. $=$ Denied; Ret.=Retire; Sch. $=$ School; NA $=$ Not Applicable; GT $=$ Get Tenure; $T D=$ Tenure Denied; NS $=$ New School. 
TABLE 10 - TURNOVER

(SEE NOTE AFTER TABLE 9)

\begin{tabular}{|c|c|c|c|c|c|c|c|}
\hline \multirow{2}{*}{\multicolumn{2}{|c|}{$\begin{array}{l}\text { Turn- } \\
\text { over } \\
\text { Group: }\end{array}$}} & \multicolumn{6}{|c|}{1981 Status: } \\
\hline & & \multirow{2}{*}{$\begin{array}{c}\begin{array}{l}\text { Had } \\
\text { Ten. }\end{array} \\
75.1 \% \\
(2129)\end{array}$} & \multirow{2}{*}{$\begin{array}{c}\begin{array}{c}\text { Ten. } \\
\text { Track }\end{array} \\
4.0 \% \\
(42)\end{array}$} & \multirow{2}{*}{$\begin{array}{c}\begin{array}{c}\text { Clin. } \\
\text { Cont. }\end{array} \\
\begin{array}{c}29.5 \% \\
(48)\end{array}\end{array}$} & \multirow{2}{*}{$\begin{array}{c}\text { LW } \\
\text { Cont. } \\
\begin{array}{c}6.0 \% \\
(6)\end{array}\end{array}$} & \multirow{2}{*}{$\begin{array}{c}\text { Other } \\
\text { Status } \\
30.9 \% \\
(104)\end{array}$} & \multirow{2}{*}{$\begin{array}{c}\text { Totals } \\
\begin{array}{l}51.9 \% \\
(2329)\end{array}\end{array}$} \\
\hline$s$ & $\begin{array}{l}\text { No } \\
\text { Event }\end{array}$ & & & & & & \\
\hline $\begin{array}{l}\mathrm{A} \\
\mathrm{Y}\end{array}$ & $\begin{array}{l}\text { Get } \\
\text { Ten. }\end{array}$ & NA & $\begin{array}{c}51.1 \% \\
(537)\end{array}$ & $\begin{array}{l}3.7 \% \\
(6)\end{array}$ & $\begin{array}{c}1.0 \% \\
(1)\end{array}$ & $\begin{array}{l}6.2 \% \\
(21)\end{array}$ & $\begin{array}{c}12.6 \% \\
(565)\end{array}$ \\
\hline \multirow{5}{*}{$\begin{array}{l}\mathrm{G} \\
\mathrm{O} \\
\mathrm{N} \\
\mathrm{E}\end{array}$} & $\begin{array}{l}\text { Ten. } \\
\text { Den. }\end{array}$ & $\mathrm{NA}$ & $\begin{array}{l}9.3 \% \\
(98)\end{array}$ & NA & NA & $\begin{array}{l}0.6 \% \\
(2)\end{array}$ & $\begin{array}{l}2.2 \% \\
(100)\end{array}$ \\
\hline & $\begin{array}{l}\text { Ret. } \\
\text { Die }\end{array}$ & $\begin{array}{r}12.0 \% \\
(340)\end{array}$ & $\begin{array}{l}1.2 \% \\
\text { (13) }\end{array}$ & $\begin{array}{c}1.2 \% \\
(2)\end{array}$ & $\overline{(0)}$ & $\begin{array}{c}12.8 \% \\
(43)\end{array}$ & $\begin{array}{l}8.9 \% \\
(398)\end{array}$ \\
\hline & $\begin{array}{l}\text { Cont. } \\
\text { Ends }\end{array}$ & NA & NA & $\begin{array}{c}16.6 \% \\
(27)\end{array}$ & $\begin{array}{c}50.0 \% \\
(50)\end{array}$ & $\begin{array}{c}13.4 \% \\
(45)\end{array}$ & $\begin{array}{l}2.7 \% \\
(122)\end{array}$ \\
\hline & $\begin{array}{l}\text { GT \& } \\
\text { Leave }\end{array}$ & NA & $\begin{array}{l}1.9 \% \\
(20)\end{array}$ & $\overline{(0)}$ & $\overline{(0)}$ & $\begin{array}{c}1.8 \% \\
(6)\end{array}$ & $\begin{array}{l}0.6 \% \\
(26)\end{array}$ \\
\hline & $\begin{array}{l}\text { Leave } \\
\text { Other }\end{array}$ & $\begin{array}{r}6.8 \% \\
(193)\end{array}$ & $\begin{array}{l}19.4 \% \\
(204)\end{array}$ & $\begin{array}{c}41.1 \% \\
(67)\end{array}$ & $\begin{array}{c}26.0 \% \\
(26)\end{array}$ & $\begin{array}{c}21.7 \% \\
(73)\end{array}$ & $\begin{array}{c}12.6 \% \\
(563)\end{array}$ \\
\hline \multirow{4}{*}{$\begin{array}{l}\text { W } \\
\text { A } \\
\text { S } \\
\text { H }\end{array}$} & $\begin{array}{l}\text { TD \& } \\
\text { Go NS }\end{array}$ & NA & $\begin{array}{l}2.3 \% \\
(24)\end{array}$ & NA & NA & $\overline{(0)}$ & $\begin{array}{l}0.5 \% \\
(24)\end{array}$ \\
\hline & $\begin{array}{l}\text { K Exp } \\
\text { Go NS }\end{array}$ & NA & NA & $\begin{array}{c}4.9 \% \\
(8)\end{array}$ & $\begin{array}{l}7.0 \% \\
(7)\end{array}$ & $\begin{array}{c}1.8 \% \\
(6)\end{array}$ & $\begin{array}{l}0.5 \% \\
(21)\end{array}$ \\
\hline & $\begin{array}{l}\text { GT \& } \\
\text { Go NS }\end{array}$ & NA & $\begin{array}{l}2.3 \% \\
(24)\end{array}$ & $\overline{(0)}$ & $\overline{(0)}$ & $\begin{array}{c}0.3 \% \\
\text { (1) }\end{array}$ & $\begin{array}{l}0.6 \% \\
(25)\end{array}$ \\
\hline & $\begin{array}{l}\text { Other } \\
\text { Go NS }\end{array}$ & $\begin{array}{r}6.1 \% \\
(173)\end{array}$ & $\begin{array}{l}8.4 \% \\
(88)\end{array}$ & $\begin{array}{c}3.1 \% \\
(5)\end{array}$ & $\begin{array}{c}10.0 \% \\
(10)\end{array}$ & $\begin{array}{c}10.7 \% \\
(36)\end{array}$ & $\begin{array}{l}7.0 \% \\
(312)\end{array}$ \\
\hline & Totals & $\begin{array}{r}100 \% \\
(2835)\end{array}$ & $\begin{array}{c}100 \% \\
(1050)\end{array}$ & $\begin{array}{l}100 \% \\
(163)\end{array}$ & $\begin{array}{l}100 \% \\
(100)\end{array}$ & $\begin{array}{l}100 \% \\
(337)\end{array}$ & $\begin{array}{c}100 \% \\
(4485)\end{array}$ \\
\hline
\end{tabular}


TABLE 11 - TURNOVER BY RAGE

(SEE NOTE AFTER TABLE 9)

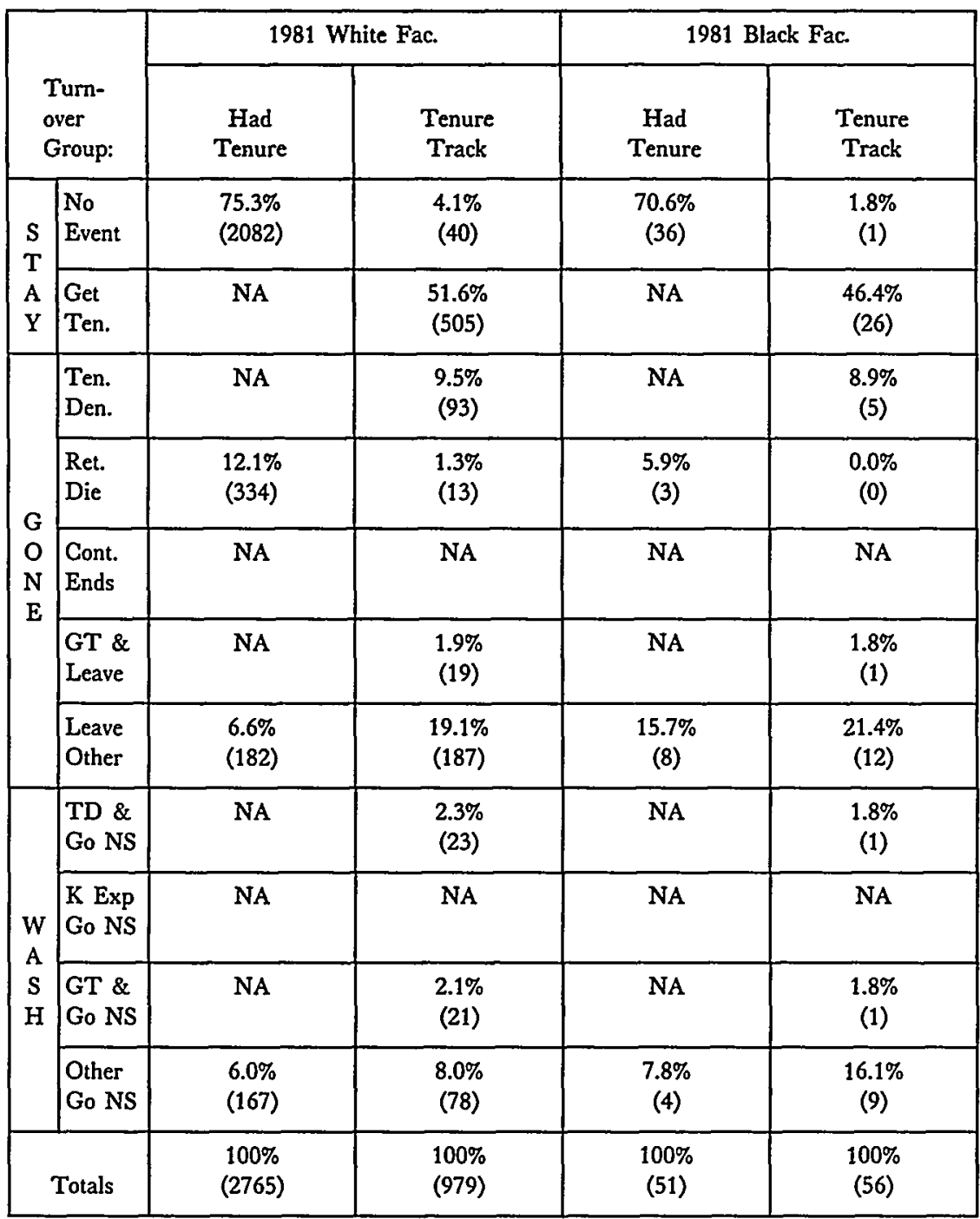


TABLE 12 - PERCENTAGE OF SCHOOLS WITH MORE THAN 6\% BLACK FACULTY BY REGION AND CITY SIZE

\begin{tabular}{|l|c|c|c|c|}
\hline & \multicolumn{4}{|c|}{ Size of Metropolitan Statistical Area: } \\
\hline \multirow{2}{*}{ Region: } & $\begin{array}{c}1 \text { Million } \\
\text { Plus }\end{array}$ & $\begin{array}{c}250,000 \text { to } \\
1,000,000\end{array}$ & $\begin{array}{c}\text { Less than } \\
250,000\end{array}$ & $\begin{array}{c}\text { Total for } \\
\text { Region }\end{array}$ \\
\hline Northeast & $\begin{array}{c}37.0 \% \\
(10 / 27)\end{array}$ & $(0 / 7)$ & $-\overline{(0 / 4)}$ & $26.3 \%$ \\
& $5.0 \%$ & $33.3 \%$ & $(10 / 38)$ \\
Midwest & $(1 / 20)$ & $(2 / 6)$ & $(0 / 7)$ & $9.1 \%$ \\
& $18.2 \%$ & $8.3 \%$ & $8.3 \%$ & $(3 / 33)$ \\
South & $(2 / 11)$ & $(1 / 12)$ & $(1 / 12)$ & $11.4 \%$ \\
West & $12.5 \%$ & $0.0 \%$ & $0.0 \%$ & $(4 / 35)$ \\
& $(2 / 16)$ & $(0 / 11)$ & $(0 / 11)$ & $(2 / 38)$ \\
\hline All & $20.3 \%$ & $8.3 \%$ & $2.9 \%$ & $13.2 \%$ \\
Regions & $(15 / 74)$ & $(3 / 36)$ & $(1 / 34)$ & $(19 / 144)$ \\
\hline
\end{tabular}

NOTE ON TABLE 12: This table excludes data for minority operated schools. The data in this table includes all full-time faculty except legal writing teachers on contract status. City size is based on 1984 data for Metropolitan Statistical Areas. States are allocated to each region as follows. Northeast includes Maine, New Hampshire, Vermont, Massachusetts, Connecticut, New York, New Jersey, Pennsylvania, Delaware, Maryland, West Virginia and the District of Columbia. The Midwest includes Ohio, Indiana, Michigan, Illinois, Missouri, Iowa, Wisconsin and Minnesota. The South includes Florida, Georgia, South Carolina, North Carolina, Virginia, Kentucky, Tennessee, Alabama, Mississippi, Arkansas, Louisiana, and Texas. The West includes all other mainland states west of the Mississippi River and Hawaii. 
TABLE 13 - PERCENTAGE OF SCHOOLS WITH MORE THAN 6\% MINORITY FACULTY BY REGION AND CITY SIZE

\begin{tabular}{|l|c|c|c|c|}
\hline & \multicolumn{4}{|c|}{ Size of Metropolitan Statistical Area: } \\
\hline \multirow{2}{*}{ Region: } & $\begin{array}{c}1 \text { Million } \\
\text { Plus }\end{array}$ & $\begin{array}{c}250,000 \text { to } \\
1,000,000\end{array}$ & $\begin{array}{c}\text { Less than } \\
250,000\end{array}$ & $\begin{array}{c}\text { Total for } \\
\text { Region }\end{array}$ \\
\hline Northeast & $44.4 \%$ & $14.3 \%$ & $25 \%$ & $36.8 \%$ \\
& $(12 / 27)$ & $(1 / 7)$ & $(1 / 4)$ & $(14 / 38)$ \\
Midwest & $15.0 \%$ & $50 \%$ & $28.6 \%$ & $24.2 \%$ \\
& $(3 / 20)$ & $(3 / 6)$ & $(2 / 7)$ & $(8 / 33)$ \\
South & $36.4 \%$ & $16.7 \%$ & $8.3 \%$ & $20.0 \%$ \\
& $(4 / 11)$ & $(2 / 12)$ & $(1 / 12)$ & $(7 / 35)$ \\
West & $31.3 \%$ & $27.3 \%$ & $18.2 \%$ & $26.3 \%$ \\
& $(5 / 16)$ & $(3 / 11)$ & $(2 / 11)$ & $(10 / 38)$ \\
\hline All & $32.4 \%$ & $25.0 \%$ & $17.6 \%$ & $27.1 \%$ \\
Regions & $(24 / 74)$ & $(9 / 36)$ & $(6 / 34)$ & $(39 / 144)$ \\
\hline
\end{tabular}

NOTE ON TABLE 13: This table excludes data for minority operated schools. The data in this table includes all full-time faculty except legal writing teachers on contract status. City size is based on 1984 data for Metropolitan Statistical Areas. States are allocated to each region in accordance with the list given in the Note to Table 12. 
TABLE 14 - PERCENTAGE OF SCHOOLS WITH MORE THAN 12\% FEMALE FACULTY BY REGION AND CITY SIZE

\begin{tabular}{|l|c|c|c|}
\hline & \multicolumn{3}{|c|}{ Size of Metro Stat. Area: } \\
\hline \multirow{2}{*}{ Region: } & $\begin{array}{c}250,000 \text { or } \\
\text { More }\end{array}$ & $\begin{array}{c}\text { Less than } \\
250,000\end{array}$ & $\begin{array}{c}\text { Total for } \\
\text { Region }\end{array}$ \\
\hline Northeast & $94.1 \%$ & $100 \%$ & $94.7 \%$ \\
& $(32 / 34)$ & $(4 / 4)$ & $(36 / 38)$ \\
Midwest & $80.8 \%$ & $71.4 \%$ & $78.8 \%$ \\
& $(21 / 26)$ & $(5 / 7)$ & $(26 / 33)$ \\
South & $76.9 \%$ & $50.0 \%$ & $68.4 \%$ \\
West & $(20 / 26)$ & $(6 / 12)$ & $(26 / 38)$ \\
& $81.5 \%$ & $63.6 \%$ & $76.3 \%$ \\
All & $(22 / 27)$ & $(7 / 11)$ & $(29 / 38)$ \\
Regions & $84.1 \%$ & $64.7 \%$ & $79.6 \%$ \\
& $(95 / 113)$ & $(22 / 34)$ & $(117 / 147)$ \\
\hline
\end{tabular}

NOTE ON TABLE 14: This table includes data for all schools except two in Puerto Rico. The data in this table includes all full-time faculty except legal writing teachers on contract status. City size is based on 1984 data for Metropolitan Statistical Areas. States are allocated to each region in accordance with the list in the Note to Table 12 . The city size breakdown in this table was limited to metropolitan areas with more or less than 250,000 people because there were no significant differences in the data for larger cities. Between $80 \%$ and $85 \%$ of the schools in each of the larger population categories had more than $12 \%$ of their faculty positions held by women. 
TABLE 15 - PERGENT FEMALE LEGAL

WRITING VERSUS PERCENT FEMALE FACULTY

(NOTE: ENTRIES ARE \% OF SCHOOLS)

\begin{tabular}{|c|c|c|c|}
\hline \multirow{2}{*}{$\begin{array}{l}\text { Percent of } \\
\text { Fegules on }\end{array}$} & \multicolumn{3}{|c|}{ Schools With \% Leg. Writing Teachers Female: } \\
\cline { 2 - 4 } Faculty & $\begin{array}{c}75 \% \text { or Less } \\
\text { Fem. Leg. Wr. }\end{array}$ & $\begin{array}{c}\text { 76\% to } 100 \% \\
\text { Fem. Leg. Wr. }\end{array}$ & $\begin{array}{c}\text { No LW } \\
\text { Program }\end{array}$ \\
\hline $0-12 \%$ & $12.5 \%$ & $29.0 \%$ & $20.9 \%$ \\
& $(4 / 32)$ & $(9 / 31)$ & $(18 / 86)$ \\
\hline $13 \%$ UP & $87.5 \%$ & $71.0 \%$ & $79.1 \%$ \\
& $(28 / 32)$ & $(22 / 31)$ & $(68 / 86)$ \\
\hline All Schs. & $100 \%$ & $100 \%$ & $100 \%$ \\
& $(32 / 32)$ & $(31 / 31)$ & $(86 / 86)$ \\
\hline
\end{tabular}

NOTE ON TABLE 15: This table includes all law schools in the sample. Legal writing teachers are those on contract status. For all three columns, $x^{2}=2.614, \mathrm{~d} f=2$, and $\mathrm{p}=.271$, not a statistically significant result. Running Fishers Test for just those schools with legal writing programs, probably the most important data, yields $\mathrm{p}=.095$, close to but not quite statistically significant.

\section{TABLE 16 - SCHOOL PRESTIGE AND PERCENTAGE \\ OF TENURED FACULTY THAT IS FEMALE \\ IN 1986-1987 ACADEMIC YEAR}

\begin{tabular}{|c|cc|cc|}
\hline $\begin{array}{l}\text { \% of Ten. } \\
\text { Fac. Fem. }\end{array}$ & \multicolumn{2}{|c|}{$\begin{array}{c}\text { Percent of "High } \\
\text { Prestige" Schools }\end{array}$} & \multicolumn{2}{c|}{$\begin{array}{c}\text { Percent of "Normal" } \\
\text { Schools }\end{array}$} \\
\hline $0-6 \%$ & $36.4 \%$ & $(8 / 22)$ & $19.7 \%$ & $(25 / 127)$ \\
$7 \%-12 \%$ & $45.5 \%$ & $(10 / 22)$ & $33.9 \%$ & $(43 / 127)$ \\
$13 \%-18 \%$ & $18.2 \%$ & $(4 / 22)$ & $28.3 \%$ & $(36 / 127)$ \\
$18 \%$ UP & & $(0 / 22)$ & $18.1 \%$ & $(23 / 127)$ \\
\hline
\end{tabular}

NOTE ON TABLE 16: $\chi^{2}=7.77, \mathrm{df}=3$, and $\mathrm{p}=.051$. 


\section{TABLE 17 - SGHOOL PRESTIGE AND PERCENTAGE OF TENURE ELIGIBLE FACULTY THAT IS FEMALE IN 1986-1987 ACADEMIC YEAR}

\begin{tabular}{|r|rr|rr|}
\hline $\begin{array}{c}\text { \% of Ten. Tr. } \\
\text { Fac. Fem. }\end{array}$ & \multicolumn{2}{|c|}{$\begin{array}{c}\text { Percent of "High } \\
\text { Prestige" Schools }\end{array}$} & \multicolumn{2}{c|}{$\begin{array}{c}\text { Percent of "Normal" } \\
\text { Schools }\end{array}$} \\
\hline $0-6 \%$ & $13.6 \%$ & $(3 / 22)$ & $15.2 \%$ & $(19 / 125)$ \\
$7 \%-12 \%$ & - & $(0 / 22)$ & $2.4 \%$ & $(3 / 125)$ \\
$13 \%-18 \%$ & $4.5 \%$ & $(1 / 22)$ & $4.0 \%$ & $(5 / 125)$ \\
$18 \%$ UP & $81.8 \%$ & $(18 / 22)$ & $78.4 \%$ & $(98 / 125)$ \\
\hline
\end{tabular}

NOTE ON TABLE 17: $\chi^{2}=.60, \mathrm{df}=3$, and $p=.896$. Note that $\mathrm{p}$ is closer to 1 than to 0 . That means there is no relationship based on prestige in this table. That, of course, is exactly the point. The number of "Normal" schools is 125 rather than 127 because two institutions had no tenure track faculty in the 1986-1987 academic year. They were excluded from this table. 
TABLE 18 - DEPARTURE AND TENURE

OF MALE AND FEMALE UNTENURED FACULTY BY GENDER COMPOSITION OF TENURED FACULTY

\begin{tabular}{|c|c|c|c|c|c|}
\hline \multirow{2}{*}{\multicolumn{2}{|c|}{$\begin{array}{l}\text { Turn- } \\
\text { over } \\
\text { Group }\end{array}$}} & \multicolumn{4}{|c|}{$\begin{array}{l}1987 \text { Tenured Fac: } 1987 \text { Tenured Fac. } \\
\text { More Than 12\% Fem: Less Than 12\% Fem }\end{array}$} \\
\hline & & $\begin{array}{l}\text { Unten. } \\
\text { Men }\end{array}$ & $\begin{array}{l}\text { Unten. } \\
\text { Women }\end{array}$ & $\begin{array}{l}\text { Unten. } \\
\text { Men }\end{array}$ & $\begin{array}{l}\text { Unten. } \\
\text { Women }\end{array}$ \\
\hline \multirow{2}{*}{$\begin{array}{l}\mathrm{S} \\
\mathrm{T} \\
\mathrm{A} \\
\mathrm{Y}\end{array}$} & $\begin{array}{l}\text { No } \\
\text { Event }\end{array}$ & $\begin{array}{l}3.7 \% \\
(13)\end{array}$ & $\begin{array}{c}5.3 \% \\
(7)\end{array}$ & $\begin{array}{l}4.2 \% \\
(19)\end{array}$ & $\begin{array}{l}2.6 \% \\
(3)\end{array}$ \\
\hline & $\begin{array}{l}\text { Get } \\
\text { Ten. }\end{array}$ & $\begin{array}{l}49.6 \% \\
(172)\end{array}$ & $\begin{array}{c}64.1 \% \\
(84)\end{array}$ & $\begin{array}{l}51.3 \% \\
(234)\end{array}$ & $\begin{array}{l}40.5 \% \\
(47)\end{array}$ \\
\hline \multirow{5}{*}{$\begin{array}{l}\mathrm{G} \\
\mathrm{O} \\
\mathbf{N} \\
\mathrm{E}\end{array}$} & $\begin{array}{l}\text { Ten. } \\
\text { Den. }\end{array}$ & $\begin{array}{l}9.8 \% \\
(34)\end{array}$ & $\begin{array}{l}3.1 \% \\
(4)\end{array}$ & $\begin{array}{l}9.2 \% \\
(42)\end{array}$ & $\begin{array}{l}15.5 \% \\
(18)\end{array}$ \\
\hline & $\begin{array}{l}\text { Ret. } \\
\text { Die }\end{array}$ & $\begin{array}{l}1.2 \% \\
(4)\end{array}$ & $\overline{(0)}$ & $\begin{array}{l}2.0 \% \\
(9)\end{array}$ & $\overline{(0)}$ \\
\hline & $\begin{array}{l}\text { Cont. } \\
\text { Ends }\end{array}$ & NA & $\mathrm{NA}$ & NA & $\mathrm{NA}$ \\
\hline & $\begin{array}{l}\text { GT \& } \\
\text { Leave }\end{array}$ & $\begin{array}{c}1.2 \% \\
(4)\end{array}$ & $\begin{array}{l}4.6 \% \\
(6)\end{array}$ & $\begin{array}{c}1.8 \% \\
(8)\end{array}$ & $\begin{array}{l}1.7 \% \\
(2)\end{array}$ \\
\hline & $\begin{array}{l}\text { Leave } \\
\text { Other }\end{array}$ & $\begin{array}{c}19.0 \% \\
(66)\end{array}$ & $\begin{array}{c}16.8 \% \\
(22)\end{array}$ & $\begin{array}{c}18.9 \% \\
(86)\end{array}$ & $\begin{array}{c}25.9 \% \\
(30)\end{array}$ \\
\hline \multirow{4}{*}{$\begin{array}{c}\text { W } \\
\text { A } \\
\text { S } \\
\text { H }\end{array}$} & $\begin{array}{l}\text { TD \& } \\
\text { Go NS }\end{array}$ & $\begin{array}{l}2.9 \% \\
(10)\end{array}$ & $\begin{array}{l}0.8 \% \\
\text { (1) }\end{array}$ & $\begin{array}{l}2.2 \% \\
(10)\end{array}$ & $\begin{array}{c}2.6 \% \\
(3)\end{array}$ \\
\hline & $\begin{array}{l}\text { K Exp } \\
\text { Go NS }\end{array}$ & NA & $\mathrm{NA}$ & NA & $\mathrm{NA}$ \\
\hline & $\begin{array}{l}\text { GT \& } \\
\text { Go NS }\end{array}$ & $\begin{array}{c}2.3 \% \\
(8)\end{array}$ & $\overrightarrow{(0)}$ & $\begin{array}{l}2.4 \% \\
(11)\end{array}$ & $\begin{array}{c}4.3 \% \\
(5)\end{array}$ \\
\hline & $\begin{array}{l}\text { Other } \\
\text { Go NS }\end{array}$ & $\begin{array}{c}10.4 \% \\
(36)\end{array}$ & $\begin{array}{c}5.3 \% \\
(7)\end{array}$ & $\begin{array}{l}8.1 \% \\
(37)\end{array}$ & $\begin{array}{c}6.9 \% \\
(8)\end{array}$ \\
\hline & Totals & $\begin{array}{l}100 \% \\
(347)\end{array}$ & $\begin{array}{l}100 \% \\
(131)\end{array}$ & $\begin{array}{l}100 \% \\
(456)\end{array}$ & $\begin{array}{l}100 \% \\
(116)\end{array}$ \\
\hline
\end{tabular}

NOTE ON TABLE 18: Comparing the two columns of data for untenured women, $\chi^{2}=48.53$, $\mathrm{df}=7$, and $\mathrm{p}=.000001$. The retired, die row was excluded. For the men and women at schools with more tenured women, $\chi^{2}=43.34, \mathrm{df}=8$, and $p<.000001$. For the men and women at schools with less tenured women, $\chi^{2}=12.26, \mathrm{df}=8$, and $\mathrm{p}=.14$. 
